\title{
Morphotaxonomic Cladistic Analysis of Rare Cestode Parasites from the Prayagraj Region (U.P.), India
}

\author{
Amarjeet Singh, Aditya Narayan, Sarvjeet Singh
}

\begin{abstract}
The present study has been conducted to investigate taxonomic aspects of the piscian cestode focusing on its morphological characters. freshwater catfish Clarias batrachus (Linnaeus, 1758) were collected from sampling stations and examined for tapeworm parasites. Six tapeworm parasites were found from its Intestine. The morphological study of cestode indicates that parasitic diversity is available in the Ganga river at Prayagraj (U.P.) region. Morphotaxonomic characters were examined as - $\mathrm{H}$, butterfly-shaped ovary, vitelline follicle cortical.
\end{abstract}

Keywords: Morphology, Morphotaxonomic, tapeworm, Cestode, Ganga River, Prayagraj (Allahabad).

\section{INTRODUCTION}

$F_{\text {ish provides essential nourishment, especially quality }}$ proteins, fats, vitamins and minerals as a macro nutritional contribution to survival and physical health. For those involved in fisheries, aquaculture and fish trade, fish is an important source of income. Government of India conducting many scientific research and projects, to increase fish supply and fulfilled nutritional rich healthy fishes are being promoted globally [1]. Fishes are parasitized by tapeworm parasites, which reduce the nutritional and market value of infected host fish because tapeworm parasites stimulate very harmful substances and consume required nutrition from the host which disturb the physiological condition of the fishes. Due to this, the weight and size of fishes reduce and ultimately lose their market value [2]. The study of tapeworm parasites is, therefore, an urgent necessity today. Very little work has been done on the taxonomy of tapeworm parasites but still, hence more exploration is required. The common helminth parasites are tapeworm (cestode) parasites. The curiosity of the author to know about the tapeworm parasites found in such fishes lead them to undertake the present project. In the present study, the author has restricted himself to the taxonomy of cestode parasites of freshwater catfish from various sampling stations (Table.1).

Revised Manuscript Received on February 12, 2020.

* Correspondence Author

Amar Jeet Singh*, Research Scholar, Department of Zoology, Institute of Basic Science, Bundelkhand University Campus, Jhansi (U.P.), India. Email - amarjeet7321@gmail.com

Aditya Narayan, Assistant Professor, Department of Zoology, Institute of Basic Science, Bundelkhand University, Jhansi (U.P.), India. Email adityanarayan21@gmail.com

Sarvjeet Singh, Research Scholar (NST), Department of NST, Science Block DTU, New Delhi, India. Email - sarvjeetsingh779@gmail.com

(c) The Authors. Published by Blue Eyes Intelligence Engineering and Sciences Publication (BEIESP). This is an open access article under the CC BY-NC-ND license (http://creativecommons.org/licenses/by-nc-nd/4.0/)

\section{MATERIAL AND METHOD}

For the taxonomical study of piscian tapeworms, the catfish Clarias batrachus (Linnaeus, 1758) were collected through different sampling station of Allahabad region of Uttar Pradesh. The alimentary canal and various organs of the fish were removed and cut open in normal saline water in the Petri dish. It was lightly shaken and its contents decanted several times. The intestine and its contents containing tapeworm parasites were examined thoroughly under a binocular microscope to ensure that none of the parasites is left behind. In some cases, the scolices of tapeworm parasites found deeply embedded, these were observed necessary to take them out by scrapping the mucosa of the intestine with a sharp scalpel or by releasing the scolices with a pair of needles. Later the portion of the mucosa attached to the tapeworms was removed by shaking the body of tapeworm in normal saline water. The worms were stretched in lukewarm water and in case of larger worms, by lifting them with the help of needles against the edges of the Petri dish repeatedly for several times and later on fixed in 5\% formalin for morphotaxonomical work. The whole-mount was stained in hematoxylin and eosin and cleared in xylene and mounted in Canada balsam. Only camera lucida drawings were made with a micrograph. All the measurements $(\mathrm{L} \times \mathrm{W})$ were measured in millimeters.

\section{DESCRIPTION}

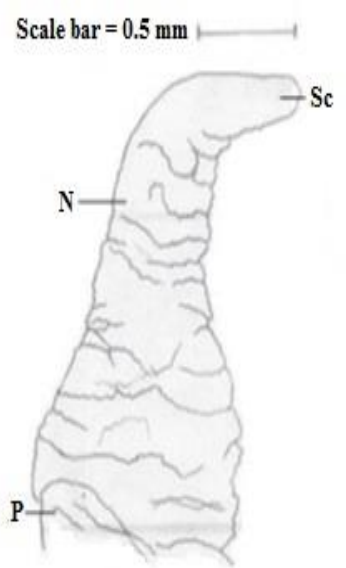

Fig.l.

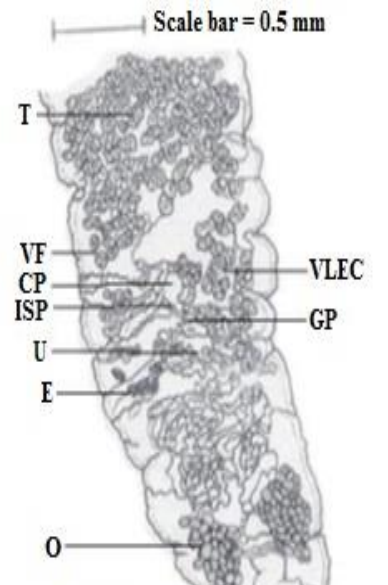

\section{Fig.2.}

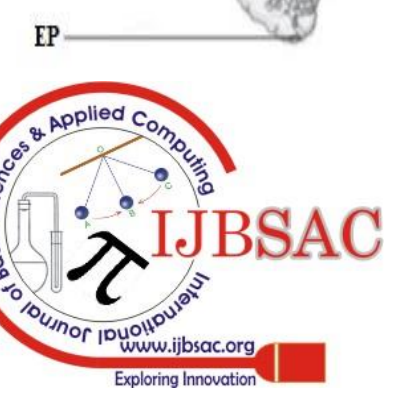




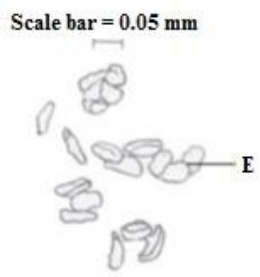

Fig.3.

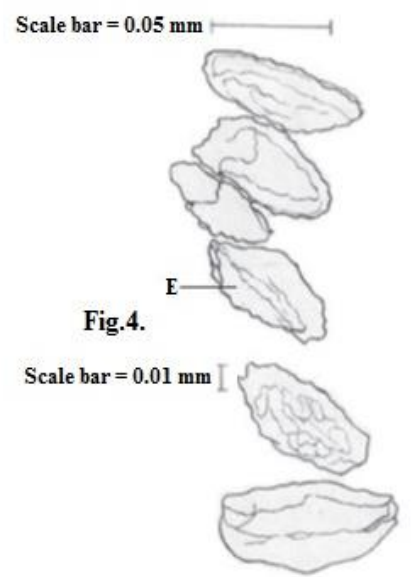

Fig. 1. The anterior part of the worm with smooth scolex and neck [50x] 2. Middle and posterior part of the worm [50x] 3. Eggs [100x] 4. Eggs (bilobed \& ovular) [450x]

Table- I: Showing statistical analysis of the population of host fishes at sampling stations

\begin{tabular}{|c|l|l|l|l|l|l|l|l|}
\hline \multicolumn{2}{|c|}{ Sampling station District - Prayagraj (Allahabad) U.P. } \\
\hline $\begin{array}{c}\text { Sr. } \\
\text { No. }\end{array}$ & $\begin{array}{c}\text { Sampling } \\
\text { station }\end{array}$ & $\begin{array}{c}\text { No. of } \\
\text { examined } \\
\text { hosts } \\
\mathbf{( a )}\end{array}$ & $\begin{array}{c}\text { No. of } \\
\text { infected } \\
\text { hosts } \\
\mathbf{( b )}\end{array}$ & $\begin{array}{c}\text { No. of } \\
\text { collected } \\
\text { parasites } \\
(\mathbf{c})\end{array}$ & $\begin{array}{c}\text { Incidence } \\
\text { of } \\
\text { infection } \\
\text { (X1) }\end{array}$ & $\begin{array}{c}\text { Intensity } \\
\text { of } \\
\text { infection } \\
\text { (X2) }\end{array}$ & $\begin{array}{c}\text { Density of } \\
\text { infection } \\
\text { (Y1) }\end{array}$ & $\begin{array}{c}\text { Index of } \\
\text { Infection } \\
\text { (Y2) }\end{array}$ \\
\hline 1. & Sirsa & 30 & 10 & 13 & 0.33 & 1.3 & 0.433 & 0.144 \\
\hline 2. & Meja & 30 & 8 & 11 & 0.26 & 1.375 & 0.366 & 0.097 \\
\hline 3. & Dandupur & 30 & 7 & 8 & 0.23 & 1.142 & 0.266 & 0.062 \\
\hline 4. & Handia & 30 & 7 & 9 & 0.23 & 1.285 & 0.3 & 0.07 \\
\hline 5. & Dighiya & 30 & 11 & 12 & 0.36 & 1.09 & 0.4 & 0.146 \\
\hline
\end{tabular}

Table- II: Showing morphometric measurement $\mathrm{L} \times \mathrm{W}$ (in $\mathbf{m m}$ ) and cladistic taxonomical characters of Genus Lytocestus Cohn13, 1908 tapeworms under generic description.

\begin{tabular}{|c|c|c|c|c|c|c|c|c|c|c|}
\hline $\begin{array}{c}\text { Sr. } \\
\text { No } \\
\text {. }\end{array}$ & $\begin{array}{c}\text { Characte } \\
\text { rs }\end{array}$ & $\begin{array}{l}\text { Lytocestus } \\
\text { clariae } \\
\text { (Redescri } \\
\text { bed) }\end{array}$ & $\begin{array}{c}\text { Pseudol } \\
\text { ytocestu } \\
\quad \text { s } \\
\text { (Pathak } \\
\text { et. al., } \\
\text { 2015) }\end{array}$ & $\begin{array}{c}\text { Lytocestus } \\
\text { osmanabade } \\
\text { nsis (Bhure } \\
\text { et. al., } \\
\text { 2010) }\end{array}$ & $\begin{array}{c}\text { Lytocestus } \\
\text { marathwadens } \\
\text { is (Shinde et } \\
\text { al, 1988) }\end{array}$ & $\begin{array}{c}\text { Lytocestus } \\
\text { folliculara } \\
\text { e (Bhure } \\
\text { et. al., } \\
\text { 2010) }\end{array}$ & $\begin{array}{l}\text { Lytocestu } \\
\quad \text { s } \\
\text { puranens } \\
\text { is (Kasar } \\
\text { et. al., } \\
\text { 2010) }\end{array}$ & $\begin{array}{c}\text { Lytocest } \\
\text { us } \\
\text { clariae } \\
\text { (Shinde, } \\
\text { G.B et. } \\
\text { al., } \\
\text { 1988) }\end{array}$ & $\begin{array}{c}\text { Lytocest } \\
\text { us } \\
\text { longicolli } \\
\text { s (Bhure } \\
\text { et. al., } \\
\text { 2010) }\end{array}$ & $\begin{array}{c}\text { Lytocestu } \\
\text { s parvulus } \\
\text { (Kasar } \\
\text { et. } \\
\text { al.,2010) }\end{array}$ \\
\hline 1 & $\begin{array}{l}\text { Length of } \\
\text { the body }\end{array}$ & 12.08 & 13.3 & 11.58 & 12.2 & 12.24 & 12.67 & 12.1 & 11.8 & 12.5 \\
\hline \multirow[t]{2}{*}{2} & $\begin{array}{l}\text { Maximum } \\
\text { breadth of }\end{array}$ & \multirow[t]{2}{*}{8.15} & \multirow[t]{2}{*}{10.25} & \multirow[t]{2}{*}{8.5} & \multirow{2}{*}{9.05} & \multirow{2}{*}{8.38} & \multirow{2}{*}{9.14} & \multirow{2}{*}{7.95} & \multirow{2}{*}{7.88} & 8.2 \\
\hline & the body & & & & & & & & & \\
\hline 3 & Neck & $0.69 \times 0.18$ & $\begin{array}{c}0.80 \times 0.2 \\
1\end{array}$ & $0.62 \times 0.20$ & $0.55 \times 0.21$ & $0.45 \times 0.17$ & $0.50 \times 0.23$ & $\begin{array}{c}0.69 \times 0.1 \\
9\end{array}$ & $\begin{array}{c}0.60 \times 0.2 \\
6\end{array}$ & $0.70 \times 0.18$ \\
\hline 4 & $\begin{array}{l}\text { Ovary: } \\
\text { shape }\end{array}$ & $\begin{array}{c}\text { H shaped like } \\
\text { a butterfly }\end{array}$ & $\begin{array}{c}\text { Inverted, } \\
\text { H } \\
\text { shaped }\end{array}$ & H shaped & $\begin{array}{c}\text { Butterfly } \\
\text { shaped }\end{array}$ & H shaped & $\begin{array}{l}\text { Inverted } \\
\text { U shaped }\end{array}$ & $\begin{array}{c}\text { Butterfly } \\
\text { shaped }\end{array}$ & $\begin{array}{l}\text { Inverted } \\
\text { A-shaped }\end{array}$ & X shaped \\
\hline 5 & $\begin{array}{l}\text { Genital } \\
\text { aperture } \\
\text { (pore) }\end{array}$ & Present & Present & Present & Present & Present & Present & Present & Present & Present \\
\hline 6 & $\begin{array}{l}\text { Vitelline } \\
\text { follicles }\end{array}$ & $0.05 \times 0.12$ & $\begin{array}{c}0.05 \times 0.1 \\
1\end{array}$ & $0.6 \times 0.12$ & $0.4 \times 0.10$ & $0.5 \times 0.13$ & $0.6 \times 0.13$ & $0.7 \times 0.11$ & $0.6 \times 0.9$ & $0.05 \times 0.10$ \\
\hline 7 & $\begin{array}{l}\text { Cirrus } \\
\text { Pouch }\end{array}$ & $\begin{array}{c}\text { Well } \\
\text { developed, } \\
\text { oval to round }\end{array}$ & $\begin{array}{c}\text { Well } \\
\text { develope } \\
\text { d }\end{array}$ & Round to oval & round & $\begin{array}{l}\text { Symmetric } \\
\text { al oval }\end{array}$ & $\begin{array}{c}\text { Round to } \\
\text { oval }\end{array}$ & $\begin{array}{c}\text { oval to } \\
\text { round }\end{array}$ & $\begin{array}{c}\text { Mostly } \\
\text { oval }\end{array}$ & $\begin{array}{c}\text { Round to } \\
\text { oval }\end{array}$ \\
\hline 7 & Eggs & $0.05 \times 0.02$ & $\begin{array}{c}0.05 \times 0.0 \\
1\end{array}$ & $0.04 \times 0.02$ & $0.05 \times 0.01$ & $0.06 \times 0.03$ & $0.04 \times 0.04$ & $\begin{array}{c}0.05 \times 0.0 \\
2\end{array}$ & $\begin{array}{c}0.05 \times 0.0 \\
3\end{array}$ & $0.06 \times 0.03$ \\
\hline 8 & $\begin{array}{l}\text { Excretory } \\
\text { pore }\end{array}$ & $0.03 \times 0.07$ & $\begin{array}{c}0.04 \times 0.0 \\
9\end{array}$ & $0.03 \times 0.08$ & $0.04 \times 0.7$ & $0.03 \times 0.07$ & $0.05 \times 0.09$ & $\begin{array}{c}0.03 \times 0.0 \\
6\end{array}$ & $\begin{array}{c}0.05 \times 0.0 \\
8\end{array}$ & $0.04 \times 0.9$ \\
\hline
\end{tabular}

Published By:

Blue Eyes Intelligence Engineering

\& Sciences Publication 


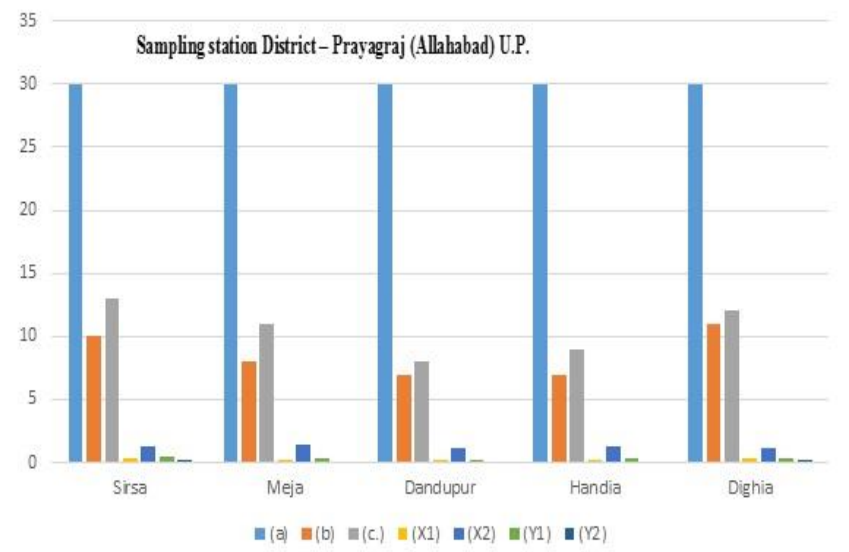

Fig. 2. Graphical presentation of sampling stations

New introducing rare tapeworm parasites of freshwater catfish (Clarias batrachus Linnaeus, 1758). Figs. (1-4) Shape, Size, Position, Measurement observed under a compound microscope with camera lucida figures. All measurements are in millimeters.

Tapeworms measure 8-12×0.42-0.94 (10×0.68).

Scolex is medium-sized, flat, smooth, blunt without any major groove, hooves and pointed spines. banded at the top measures $0.64-0.74 \times 0.12-0.24(0.69 \times 0.18)$. Neck present with under segmented proglottids measures $0.68-0.75 \times 0.59-0.45(0.71 \times 0.52)$. Proglottids present.

Numerous testes are present in the medullary region, numerable. oval to round shaped Measures $0.08-0.16 \times 0.07-0.11(0.12 \times 0.09)$. Vas deferens are visible. Vitelline Follicle present in the cortical region. VF never touches the ovarian lobes. Uterus extends the posterior region to the ovary. Uterus long, non-glandular, coiled medullary, situated posterior and anterior to the ovarian isthmus.

Cirrus pouch well-developed oval to round with internal seminal vesicle. Median measures $0.36-0.30 \times 0.18-0.14$ $(0.33 \times 0.16)$. Genital aperture present.

Ovary $\mathrm{H}$ shaped like a butterfly, both arms even, lateral lobes of ovary situated in cortical and medullary regions measures $0.30-0.32 \times 0.44-0.42(0.31 \times 0.43)$ behind the cirrus pouch. Genital pore present at the posterior region of the worm. Isthmus present and curved in the medullary region anterior uterus measures $0.04-0.06 \times 0.22-0.24(0.05 \times 0.23)$.

Excretory pore measures $0.02-0.04 \times 0.08-0.06$ $(0.03 \times 0.07)$. Eggs are some oval and bilobed, broader than length, coffee bean-like shape and operculate structure measures $0.04-0.06 \times 0.02-0.03(0.05 \times 0.02)$.

\section{RESULT AND DISCUSSION}

The present parasite form comes closer to genera Lytocestus, Pseudolytocestus.

This form differs from Pseudolytocestus in having well developed banded scolex, external seminal vesicle absent, internal seminal vesicle present, ovary $H$ shaped like butterfly and uterus extend up to post ovarian region [3].

1) The present form differs from Lytocestus osmanabadensis (Bhure et. al., 2010) in having a well-developed Scolex with neck, ovary $\mathrm{H}$ shaped, and bilobed eggs $[4,5]$.

2) The present form differs from Lytocestus marathwadensis (Shinde et al, 1988) in having medium

size worm with well-developed scolex, $\mathrm{H}$ shaped ovary, uterus extend up to post ovarian region and bilobed, operculated eggs [6].

3) The Present form differs from Lytocestus follicularae (Bhure et. al., 2010) having mediums size of worm, $\mathrm{H}$ butterfly-shaped ovary in absence of Mehlis gland [7].

4) The present form differs from Lytocestus puranensis (Kasar et. al., 2010) in having a well-developed Scolex with neck, internal seminal vesicle present, and $\mathrm{H}$ shaped ovary [8].

5) This form differs from Lytocestus clariae in having medium-sized worms, presence of neck (under segmented), presence of internal seminal vesicle and butterfly-shaped ovary [9].

6) The present form differs from Lytocestus longicollis in having internal seminal vesicle, $\mathrm{H}$ shaped ovary and bilobed eggs [10].

7) The present form differs from Lytocestus parvulus in having an $\mathrm{H}$ shaped ovary and bilobed, operculate eggs [11].

8) Thus the studied parasites show the taxonomic difference from all known genera of the family Lytocestidae.

\section{Taxonomic Summary}

Family : Lytocestidae Wardle et McLeod, 1952 [12]

Genus : Lytocestus Cohn, 1908 [13]

Species : clariae (Redescribed)

Host : $\quad$ Claris batrachus (Linn. 1758) [14]

Habitat : Intestine

Locality : Ganga river at Prayagraj district (U.P.)

Number of parasites : 02/06

\section{CONCLUSION}

The Lytocestus genus is one of the most important Caryophyllidea cestodes of Clarias batrachus in the Ganga river at the Prayagraj region. The morphological diversity of its population is found in the host. The spawning season of host fish, physiological and environmental factors, availability of infected food may be associated causes for its invasion, development, and variation. In case of heavy infection, it can cause serious injuries by its scolex and hooks penetration to the fish intestine. Further research is therefore necessary for observing the morphotaxonomy, histology and cladistics morphometry.

\section{ACKNOWLEDGMENTS}

The authors are thankful to the Head, Department of Zoology, Institute of Basic Science, Bundelkhand University Campus, Jhansi (India) for providing the Laboratory facilities and valuable suggestions.

Published By: \& Sciences Publication

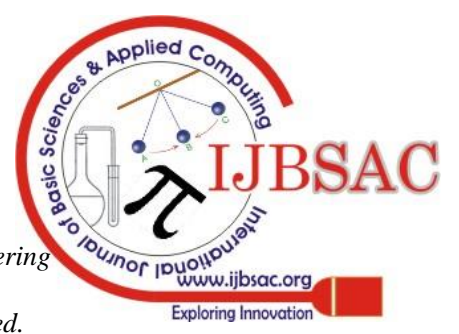




\section{REFERENCES} portal of India. https://www.india.gov.in/topics/agriculture/fisheries

2. Case studies on fish loss assessment of small-scale fisheries in Indonesia, FIAM/C1129 (En), FAO Fisheries and Aquaculture Circular, ISSN 2070-6065.

3. Pathak, A. and Srivastav, A.K. (2015) morphotaxonomical study of a new cestode, Pseudoclariasis pandei n.g., n.sp from catfish, Clarias batrachus Linn., Flora and Fauna. 2015 Vol. 21 No. 1 PP 15-20, ISSN 09716920.

4. Bhure, D.B., and Nanware, S.S.( 2015) Faunestic Diversity and Distribution of Cestode Parasites of Piscean, Avian and Mammalian Host, American Journal of Biology and Life Sciences 2015; 3(6): 241-245 (http://www.openscienceonline.com/journal/ajbls)

5. Bhure, D. B., Waghmare, S.B., Kasar, C.R. and Shaikh, K.M. 2010 Taxonomic Observation of the Caryophyllidean Tapeworm Lytocestus Cohn, 1908 from Clarias batrachus (Linneus, 1758). Journal of Ecology and Environmental Sciences 1(1): 01-06.

6. Shinde, G. B., and Phad, A. N. 1988. On a new Cestode Lytocestus marathwadensis from freshwater fish. Riv. Di. Para. 47 (2): 295-298.

7. Bhure, D. B., Waghmare, S.B., Kasar, C.R. and Shaikh, K.M. 2010. Taxonomic Observation of the Caryophyllidean Tapeworm Lytocestus Cohn, 1908 from Clarias batrachus (Linneus, 1758). Journal of Ecology and Environmental Sciences 1(1): 01-06.

8. Kasar, Chandrashekhar Rameshwar, Bhure, Dhanraj Balbhim, Nanware, Sanjay Shamrao and Sonune, M.B. 2010. New species of the caryophyllidean tapeworm Lytocestus Cohn,1908 from Clarius batrachus (Linneus,1758). The Asian Journal of Animal Science. Vol. 5(2): pp 219-222.

9. Tendon, V., Chakravarty, R. and Das, B. 2005. Four new species of the genus Lytocestus (Caryophyllidea, Lytocestidae) from Edible Catfishes in Assam and Meghalaya, India. Journal of Parasitic Diseases Vol. 29 (2) December 2005, pp. 131

10. Rama Devi P. 1973. Lytocestus longicollis sp. nov. (Cestoidea: Caryophyllidea) from catfish Clarias batrachus (L.) in India. Journal of Helminthology. 47: 415-420.

11. Furtado JI. 1963. A new caryophyllaeid cestode, Lytocestus parvulus sp. nov. from a Malayan catfish. Annal and Magazine of Natural History (Ser B). 6: 93-106.

12. Wardle RA. and McLeod JA. 1952. The Zoology of tapeworms. University of Minnesota Press, Minneapolis, pp 780.

13. Kasar, Chandrashekhar Rameshwar, Bhure, Dhanraj Balbhim, Nanware, Sanjay Shamrao and Sonune, M.B. 2010. New species of the caryphyllidean tapeworm Lytocestus Cohn,1908 from Clarius batrachus (Linneus,1758). The Asian Journal of Animal Science. Vol. 5(2): pp 219-222.

14. Linnaeus, C. 1758. Systema Naturae per regna tria naturae, secundum classes, ordines, genera, species, cum characteribus, differentiis, synonymis, locis. Editio Decima, Reformata. Tomus I. Laurentii Salvii, Stockholm. 824 pp. DOI: 10.5962/bhl.title.542 BHL

\section{AUTHORS PROFILE}

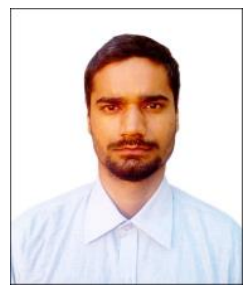

Amar Jeet Singh, Research Scholar (Zoology), Parasitology Laboratory, Department of Zoology, Institute of Basic Science, Bundelkhand University Campus, Jhansi (U.P.) India. Present working project: Taxonomy of piscian cestodes of fresh water fish. Specialization: Parasitology \& Immunology Ph.09536269919 Email - amarjeet7321@gmail.com

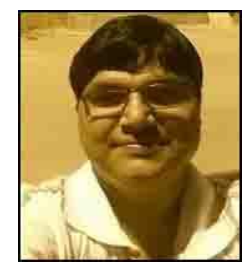

Aditya Narayan, Assistant Professor, Department of Zoology, Institute of Basic Science, Bundelkhand University, Jhansi (U.P.) India. Email adityanarayan21@gmail.com

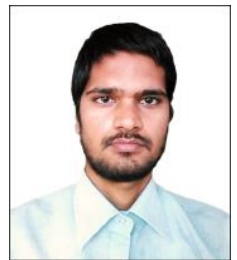

Sarvjeet Singh, Research Scholar (NST), Department of NST, Science Block, DTU, New Delhi Ph.- $08630624604 \quad$ Email sarvjeetsingh779@gmail.com 